\title{
Faktor Risiko Tumor Ganas Payudara Pada Pasien Rawat Jalan RSUD Andi Makkasau Kota Parepare
}

\section{The Risk Factors Tumor of the Breast in an Outpatient RSUD Andi Makkasau Parepare City}

\author{
Nurul Magfirah ${ }^{(1)}$, Haniarti, Rini Anggraeny ${ }^{(1)}$ \\ ${ }^{(1)}$ Program Studi Kesehatan Masyarakat Fakultas Ilmu Kesehatan, Universitas \\ Muhammadiyah Parepare, Sulawesi Selatan
}

Korespondensi Penulis: Nurul Magfirah, Program Studi Kesehatan Masyarakat Fakultas Ilmu Kesehatan, Universitas Muhammadiyah Parepare Email: nurulmagfirah.health16@gmail.com

\begin{abstract}
ABSTRAK
Hasil pemeriksaan deteksi dini kanker payudara di Indonesia Tahun 2017 telah ditemukan 12.023 tumor payudara, dan 3.079 curiga kanker payudara. Di antara 5 kanker yang paling sering dijumpai, kanker payudara tercatat mencapai 2,09 juta kasus. Untuk mencari faktor risiko tumor ganas payudara seperti usia, riwayat melahirkan, riwayat menyusui, riwayat keluarga, riwayat menopause, dan riwayat pemakaian alat kontrasepsi hormonal. Metode survei analitik dengan desain case control dengan jumlah sampel 80 responden yang terbagi atas sampel kasus sebanyak 40 responden dan sampel kontrol sebanyak 40 responden. Teknik pengambilan sampel adalah consecutive sampling dengan uji Chi-Square dan Odds Ratio. Faktor yang ditemukan sebagai faktor risiko meliputi usia $(\mathrm{OR}=19,0$; CI95\%=4,02-89,6), riwayat melahirkan $(\mathrm{OR}=2,17$; CI95\%=1,70-2,78), riwayat kanker dalam keluarga $(\mathrm{OR}=6,33$; $\mathrm{CI} 95 \%=1,28-31,1)$, riwayat menopause $(\mathrm{OR}=2,33$; $\mathrm{CI} 95 \%=1,78-3,05)$, riwayat pemakaian alat kontrasepsi hormonal $(\mathrm{OR}=6,33$; CI95\%=1,50-14,4), sedangkan riwayat menyusui tidak termasuk faktor risiko $(\mathrm{OR}=1,00 ; \mathrm{CI} 95 \%=0,39-2,50)$. Sebaiknya peneliti selanjutnya melakukan uji multivariat, uji interaksi, dan confounding. Diharapkan petugas kesehatan melakukan penyuluhan tentang pemakaian kontrasepsi hormonal $\geq 5$ tahun yang dapat meningkatkan kejadian tumor ganas payudara.
\end{abstract}

Kata Kunci: Tumor Ganas Payudara, Umur, Melahirkan, Keluarga, Menopause, KB Hormonal

\begin{abstract}
Early detection of breast cancer in Indonesia in 2017 has revealed 12023 breast tumors, and 3079 suspected breast cancer. Of the 5 most common cancers,breast cancer has been recorded at 2.09 million cases. To determine the risk factor of malignant breast tumor such as age, birth history, breast feeding history, family history, menopouse history, and history of hormonal contraception. This research method is an analytic survey method designed case control with the number of samples of 80 divided respondents on the case sample of 40 respondents and control samples of 40 respondens. Sample retrieval techniques in this study are consecutive sampling with test chi-square and odds ratio. The factors found as a risk factor include age (OR=19.0; CI 95\% = 4.02-89.6), birth history $(\mathrm{OR}=2.17 ; \mathrm{Cl} 95 \%=1.70-2.78)$, family history $(\mathrm{OR}=6.33 ; \mathrm{Cl} 95 \%=1.28-31.1)$, menopause history $(O R=2.33 ; \mathrm{Cl} 95 \%=1.78-3.05)$, history of hormonal contraception $(O R=6.33$; $\mathrm{Cl} 95 \%=1.50-14.4)$, while the history of breast feeding is not a risk factor $(\mathrm{OR}=1.00 ; \mathrm{Cl} 95 \%=$ 0.39-2.50). Should the next researcher do multivariate tests, interaction tests, and counfounding. It is expected that health officials are counseling about hormonal contraception $\geq 5$ years that can increase the incidence of breast malignant tumors.
\end{abstract}

Keywords: Risk Factors Tumor Of The Breast, Age, Childbirth Family, Menopouse, KB Hormonal 


\section{PENDAHULUAN}

Tumor atau neoplasma adalah pertumbuhan sel yang berlebihan dalam tubuh yang bersifat jinak dan ganas. Kanker payudara merupakan tumor ganas payudara yang berasal dari jaringan payudara dan jaringan penunjang lainnya. Tumor ganas payudara adalah penyebab kematian paling umum pada wanita akibat kanker. Benjolan pada payudara merupakan indikasi adanya jenis tumor atau kanker payudara (Fauzia, 2019).

Menurut World Health Organization (WHO) Tahun 2018, kanker merupakan penyebab kematian nomor dua di dunia. Tahun 2018 terdapat 9,6 juta kematian akibat kanker dan sekitar 1 dari 6 kematian disebabkan oleh kanker. Di antara 5 kanker yang paling sering dijumpai, kanker payudara tercatat mencapai 2,09 juta kasus (Astria et al., 2020).

Hasil pemeriksaan deteksi dini kanker payudara di Indonesia Tahun 2017 telah ditemukan 12.023 tumor payudara, dan 3.079 curiga kanker payudara (Kemenkes RI, 2018). Data Dinas Kesehatan Provinsi Sulawesi Selatan Tahun 2017 menyebutkan jumlah kasus kanker payudara yaitu 252 di Rumah Sakit dan 600 di Puskesmas (Rukinah, 2019). Penderita tumor ganas payudara/kanker payudara pada pasien rawat jalan di RSUD Andi Makkasau Kota Parepare Tahun 2017 sebanyak 498 penderita, Tahun 2018 mengalami peningkatan sebanyak 598 penderita, dan Tahun 2019 mengalami penurunan sebanyak 175 penderita. Penyebab tumor ganas payudara pada wanita memiliki beberapa faktor, seperti usia, riwayat melahirkan, riwayat menyusui, riwayat keluarga, riwayat menopouse, dan riwayat pemakaian alat kontrasepsi hormonal.

Wanita dengan usia $\geq 30$ tahun memiliki peluang 14,00 kali lebih berisiko mengalami kanker payudara dibanding dengan wanita berusia $<30$ tahun. Pada usia $\geq 30$ tahun atau 40 tahun keatas disebut masa pramenopouse, pada masa ini hormon estrogen dan progesteron tidak dapat dihasilkan dengan jumlah yang cukup sehingga produksi hormon estrogen semakin meningkat dan hal inilah yang akan memicu untuk terjadinya kanker (Rahayu \& Arania, 2018).

Wanita yang tidak pernah melahirkan memiliki peluang 9,333 kali lebih berisiko dibandingkan dengan wanita yang pernah melahirkan. Hal ini secara tidak langsung berhubungan dengan riwayat menyusui, dimana pada wanita yang menyusui kadar estrogen dan progesteron akan tetap rendah selama menyusui sehingga mengurangi pengaruh hormon tersebut terhadap proses poliferasi jaringan termasuk jaringan payudara (Setiadharma et al., 2019).

Wanita yang menyusui tapi $<2$ tahun memiliki peluang 5,6 kali lebih berisiko mengalami kejadian kanker payudara dibanding wanita yang pernah menyusui $\geq 2$ tahun. Waktu menyusui yang lebih lama mempunyai efek yang positif dalam menurunkan risiko kanker payudara. Dengan memberikan ASI lebih lama terjadi penurunan kadar hormon estrogen dan pengeluaran bahan-bahan pemicu kanker selama proses menyusui, semakin lama waktu menyusui semakin besar efek perlindungan terhadap kanker payudara yang ada (Sukmeyenti \& Sari, 2019)

Wanita yang memiliki keluarga dengan riwayat kanker payudara memiliki peluang 9,056 kali lebih berisiko dibanding dengan wanita yang tidak memiliki keluarga dengan riwayat kanker payudara. Semakin muda anggota keluarga tersebut terkena kanker payudara maka akan semakin besar pula penyakit tersebut bersifat menurun. Wanita yang memiliki hubungan kekeluargaan dengan penderita kanker payudara memiliki risiko yang lebih besar, terutama jika hubungannya dekat. Hal ini karena mutasi gen yang mungkin diwarisi oleh keluarga dekatnya (Maulinasari et al., 2018).

Wanita dengan usia menopouse $\geq$ 50 tahun memiliki peluang 2,935 kali lebih berisiko dibanding usia menopouse $<50$ tahun. Pada wanita yang mengalami awal menopouse usia yang lebih tua berarti lebih lama terpapar dengan tingginya kadar hormon estrogen dalam darah. Sedangkan peran hormon estrogen pada wanita menopause adalah tingkat 
estrogen yang lebih tinggi pada seorang wanita akan menghambat terjadinya menopouse sehingga mengembangkan risiko terjadinya kanker payudara (Neila et al., 2018).

Wanita yang menggunakan kontrasepsi hormonal selama $\geq 5$ tahun memiliki peluang 2,810 kali berisiko dibanding wanita yang tidak menggunakan kontrasepsi hormonal (Nissa et al., 2017). Pemakaian kontrasepsi hormonal dapat menyebabkan terjadinya peningkatan paparan hormon estrogen dalam tubuh. Adanya peningkatan paparan hormon estrogen tersebut yang dapat memicu pertumbuhan sel pada kelenjar payudara yang tidak normal sehingga dapat menimbulkan adanya kanker (Nissa et al., 2017).

Penyebab kejadian tumor/kanker payudara tidak diketahui, tetapi kemungkinan multifaktorial yaitu dikarenakan beberapa faktor seperti faktor usia, riwayat melahirkan, riwayat menyusui, riwayat keluarga, usia menopouse, dan pemakaian alat kontrasepsi hormonal (Fauzia, 2019). Oleh karena itu peneliti tertarik melakukan penelitian yang berjudul Faktor Risiko Tumor Ganas Payudara pada Pasien Rawat Jalan RSUD Andi Makkasau Kota Parepare.

\section{SUBJEK DAN METODE}

Metode penelitian yang digunakan adalah metode survei analitik dengan desain penelitian case control. Penelitian ini dilakukan di RSUD Andi Makkasau Kota Parepare pada bulan Juli sampai Agustus 2020. Populasi kasus dalam penelitian ini adalah wanita yang terdiagnosis tumor ganas payudara yang rawat jalan di RSUD Andi Makkasau, dan populasi kontolnya yaitu wanita yang tidak terdiagnosis tumor. Besar sampel pada penelitian ini adalah sebayak 80 responden, dengan sampel kasus sebanyak 40 responden dan sampel kontrol sebanyak 40 responden. Analisis data yang digunakan adalah analisis univariat (distribusi frekuensi) dan analisis bivariat (Chi-Square dan Odds Ratio) dengan teknik pengambilan sampel secara consecutive sampling yaitu semua yang memenuhui kriteria inklusi maka dijadikan sampel. Kriteria inklusi sampel kasus meliputi (a) Perempuan yang memiliki benjolan di payudara berdasarkan hasil USG dan diagnosis dokter; (b) Bersedia menjadi responden baik kontak langsung ataupun melalui survei telepon; (c) Dapat berkomunikasi dengan baik. Kriteria inklusi sampel kontrol meliputi (a) Perempuan yang tidak memiliki benjolan di payudara berdasarkan hasil USG dan diagnosis dokter; (b) Bersedia menjadi responden baik kontak langsung ataupun melalui survei telepon; (c) Dapat berkomunikasi dengan baik Instrumen dalam penelitian ini adalah kuesioner, telepon, alat tulis dan aplikasi SPSS dalam pengolahan data.

\section{HASIL}

Tabel 1. Distribusi Karakteristik Responden di RSUD Andi Makkasau Kota Parepare Tahun 2020

\begin{tabular}{|c|c|c|c|c|c|c|}
\hline \multirow{3}{*}{ Variabel } & \multicolumn{4}{|c|}{ Kejadian Tumor Ganas Payudara } & \multirow{2}{*}{\multicolumn{2}{|c|}{ Total }} \\
\hline & \multicolumn{2}{|c|}{ Kasus } & \multicolumn{2}{|c|}{ Kontrol } & & \\
\hline & $\mathbf{n}$ & $\%$ & $\mathbf{n}$ & $\%$ & $\mathbf{n}$ & $\%$ \\
\hline \multicolumn{7}{|l|}{ Usia } \\
\hline$\geq 30$ tahun & 38 & 95,0 & 20 & 50,0 & 58 & 72,5 \\
\hline$<30$ tahun & 2 & 5,0 & 20 & 50,0 & 22 & 27,5 \\
\hline \multicolumn{7}{|l|}{ Status Melahirkan } \\
\hline Tidak Pernah Melahirkan & 6 & 15,0 & 0 & 0,0 & 6 & 7,5 \\
\hline Pernah Melahirkan & 34 & 85,0 & 40 & 100,0 & 74 & 92,5 \\
\hline \multicolumn{7}{|l|}{ Status Menyusui } \\
\hline Tidak Menyusui & 10 & 25,0 & 4 & 10,0 & 14 & 17,5 \\
\hline Pernah Menyusui < 2 tahun & & & & & & \\
\hline \multirow[t]{2}{*}{ Pernah Menyusui $\geq 2$ tahun } & 16 & 40,0 & 22 & 55,0 & 38 & 47,5 \\
\hline & 14 & 35,0 & 14 & 35,0 & 28 & 35,0 \\
\hline
\end{tabular}


42 Nurul Magfirah, Haniarti, Rini Anggraeny Faktor Risiko Tumor Ganas Payudara Pada Pasien...

\begin{tabular}{|c|c|c|c|c|c|c|}
\hline \multicolumn{7}{|l|}{ Status Riwayat Keluarga } \\
\hline Memiliki & 10 & 25,0 & 2 & 5,0 & 12 & 15,0 \\
\hline Tidak Memiliki & 30 & 75,0 & 38 & 95,0 & 68 & 85,0 \\
\hline \multicolumn{7}{|l|}{ Status Menopause } \\
\hline Menopause $\geq 50$ tahun & 10 & 25,0 & 0 & 0,0 & 10 & 12,5 \\
\hline Menopause $<50$ tahun & 5 & 12,5 & 0 & 0,0 & 5 & 6,3 \\
\hline Tidak Menopouse & 25 & 62,5 & 40 & 100,0 & 65 & 813 \\
\hline \multicolumn{7}{|l|}{ Kontrasepsi Hormonal } \\
\hline Memakai $\geq 5$ tahun & 16 & 40,0 & 5 & 12,5 & 21 & 26,3 \\
\hline Memakai $<5$ tahun & 4 & 10,0 & 23 & 57,5 & 27 & 33,8 \\
\hline Tidak Memakai & 20 & 50,0 & 12 & 30,0 & 32 & 40,0 \\
\hline
\end{tabular}

Sumber: Data Primer

Distribusi responden berdasarkan Tabel 1, menunjukkan bahwa wanita paling banyak menderita tumor ganas pasyudara pada usia $\geq 30$ tahun yaitu 38 orang $(95,0 \%)$ pada kelompok kasus dan 28 orang $(50,0 \%)$ pada kelompok kontrol. Responden yang tidak pernah melahirkan pada kelompok kasus sebanyak 6 orang $(15,0 \%)$ dan semua kelompok kontrol pernah melahirkan. Responden yang tidak pernah menyusui sebanyak 10 orang (25.0\%) pada kelompok kasus dan kelompok kontrol sebanyak 4 orang $(10,0 \%)$. Responden yang pernah menyusui $<2$ tahun sebanyak 16 orang
(40,0\%) pada kelompok kasus dan kelompok kontrol sebanyak 22 orang $(55,0 \%)$. Responden yang memiliki riwayat keluarga sebanyak 10 orang $(25,0 \%)$ pada kelompok kasus dan kelompok kontrol sebanyak 2 orang $(5,0 \%)$. Responden yang mengalami menopouse $\geq 50$ tahun sebanyak 10 orang $(25,0 \%)$ pada kelompok kasus dan kelompok kontrol tidak ada yang mengalami menopouse. Responden yang memakai alat kontrasepsi hormonal $\geq 5$ tahun sebanyak 16 orang $(40,0 \%)$ pada kelompok kasus dan kelompok kontrol sebanyak 5 orang $(12,5 \%)$.

Tabel 2. Distribusi Besar Risiko Variabel IndependenTerhadap Kejadian Tumor Ganas Payudara di RSUD Andi Makkasau Kota Parepare Tahun 2020

\begin{tabular}{|c|c|c|c|c|c|c|c|c|c|}
\hline \multirow{3}{*}{$\begin{array}{c}\text { Variabel } \\
\text { Independen }\end{array}$} & \multicolumn{4}{|c|}{$\begin{array}{c}\text { Kejadian Tumor Ganas } \\
\text { Payudara }\end{array}$} & \multirow{2}{*}{\multicolumn{2}{|c|}{ Total }} & \multirow[t]{3}{*}{$\begin{array}{c}p- \\
\text { value }\end{array}$} & \multirow[t]{3}{*}{ OR } & \multirow[t]{3}{*}{$\begin{array}{l}\text { CI 95\% } \\
\text { (LL-UL) }\end{array}$} \\
\hline & \multicolumn{2}{|c|}{ Kasus } & \multicolumn{2}{|c|}{ Kontrol } & & & & & \\
\hline & $n=40$ & $\%$ & $n=40$ & $\%$ & $\mathrm{n}=\mathbf{8 0}$ & $\%$ & & & \\
\hline \multicolumn{10}{|l|}{ Usia } \\
\hline Berisiko & 38 & 95,0 & 20 & 50,0 & 58 & 72,5 & 0,000 & 19,0 & $4,02-$ \\
\hline Tidak & & & & & & & & & 89,6 \\
\hline Berisiko & 2 & 5,0 & 20 & 50,0 & 22 & 27,5 & & & \\
\hline \multicolumn{10}{|l|}{$\begin{array}{l}\text { Riwayat } \\
\text { Melahirkan }\end{array}$} \\
\hline Berisiko & 6 & 15,0 & 0 & 0,0 & 6 & 7,5 & 0,026 & 2,17 & $1,70-$ \\
\hline Tidak & & & & & & & & & 2,78 \\
\hline Berisiko & 34 & 85,0 & 40 & 100,0 & 74 & 92,5 & & & \\
\hline \multicolumn{10}{|l|}{$\begin{array}{l}\text { Riwayat } \\
\text { Menyusui }\end{array}$} \\
\hline Berisiko & 26 & 65,0 & 26 & 65,0 & 52 & 65,0 & 1,000 & 1,00 & 0,39- \\
\hline $\begin{array}{l}\text { Tidak } \\
\text { Berisiko }\end{array}$ & 14 & 35,0 & 14 & 35,0 & 28 & 35,0 & & & 2,50 \\
\hline \multicolumn{10}{|l|}{$\begin{array}{l}\text { Riwayat } \\
\text { Keluarga }\end{array}$} \\
\hline Berisiko & 10 & 25,0 & 2 & 5,0 & 12 & 15,0 & 0,025 & 6,33 & $1,28-$ \\
\hline Tidak & & & & & & & & & 31,1 \\
\hline Berisiko & 30 & 75,0 & 38 & 95,0 & 68 & 85,0 & & & \\
\hline
\end{tabular}




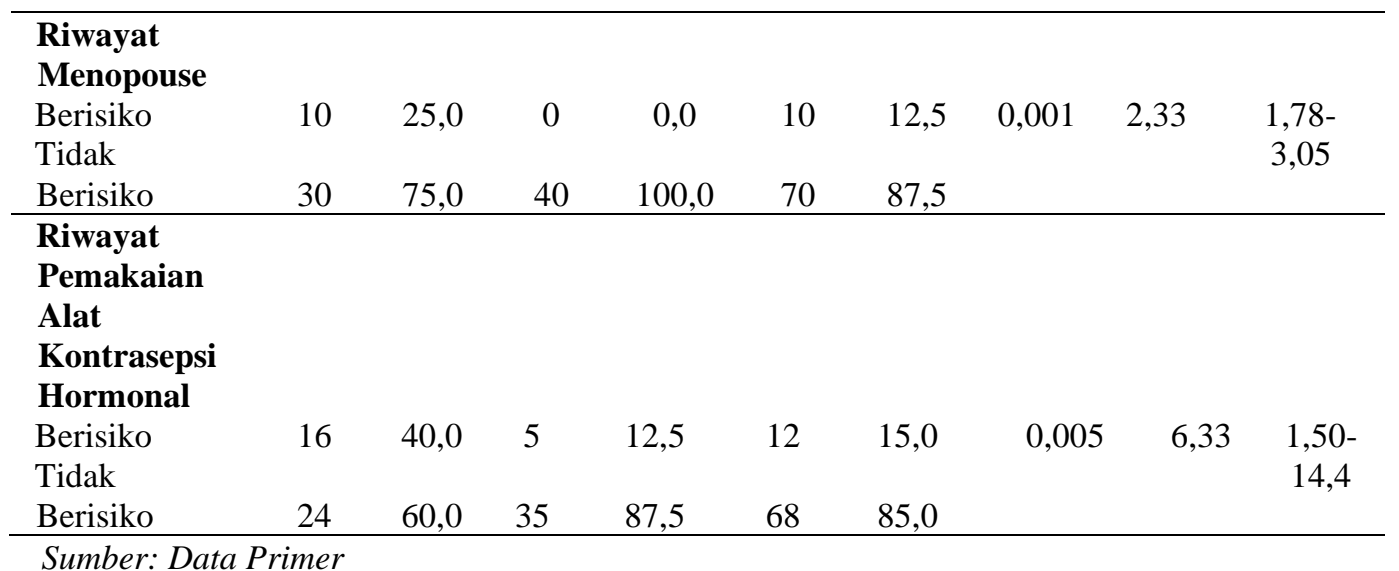

Tabel 2 menunjukan bahwa analisis berdasarkan usia didapatkan nilai OR 19,0 dan tingkat kepercayaan $(\mathrm{Cl})$ $95 \%$ 4,02-89,6. Artinya usia $\geq 30$ tahun secara signifikan merupakan faktor risiko kejadian tumor ganas payudara. Hal ini menunjukkan bahwa wanita usia $\geq 30$ tahun berisiko 19,0 kali untuk mengalami tumor ganas payudara dibanding yang berusia $<30$ tahun.

Analisis riwayat melahirkan memberikan hasil OR sebesar 2,17 dengan tingkat kepercayaan (CI) 95\% 1,70-2,78. Berdasarkan hasil analisis riwayat melahirkan merupakan faktor risiko tumor ganas payudara. Wanita yang tidak pernah melahirkan memiliki risiko secara bermakna sebesar 2,17 kali dibanding dengan wanita yang pernah melahirkan anak. Adapun hasil analisis riwayat menyusui menunjukkan nilai OR 1,00 dan $\mathrm{Cl} 195 \%$ 0,39-2,50. Artinya riwayat menyusui bukan faktor risiko kejadian tumor ganas payudara. Nilai OR 1,00 artinya wanita yang menyusui selama $<2$ tahun memiliki peluang 1,00 kali berisiko terkena tumor ganas payudara dibanding dengan wanita yang menyusui selama $\geq 2$ tahun.

Pada riwayat keluarga terhadap kejadian tumor ganas payudara didapatkan nilai OR 6,33 dengan tingkat kepercayaan (Cl) $\quad 95 \% \quad 1,28-31,1$. Analisis tersebut menunjukkan adanya hubungan yang signifikan. Wanita yang memiliki keluarga yang pernah menderita tumor atau kanker payudara memiliki risiko 6,33 kali mengalami tumor ganas payudara. Sedangkan pada variabel riwayat menopause memiliki hubungan yang bermakna terhadap kejadian tumor ganas payudara. Hasil analisis menunjukkan nilai OR 2,33 pada tingkat kepercayaan (Cl) 95\% 1,78-3,05. Jadi, dapat disimpulkan bahwa wanita dengan riwayat menopause $\geq 50$ tahun berisiko 2,33 kali terkena tumor ganas payudara dibanding dengan wanita yang menopouse usia $<50$ tahun. Analisis riwayat pemakaian alat kontrasepsi hormonal didapatkan nilai OR sebesar 6,33 pada tingkat kepercayaan $(\mathrm{Cl}) 95 \%$ 1,28-31,1. Analisis tersebut memiliki pengaruh yag signifikan terhadap kejadian tumor ganas payudara. Wanita yang memakai alat kontrasepsi hormonal $\geq 5$ tahun memiliki peluang 6,33 kali menderita tumor ganas payudara dibanding wanita yang memakai alat kontrasepsi hormonal $<5$ tahun.

\section{DISKUSI \\ Risiko Usia terhadap Kejadian Tumor Ganas Payudara}

Kanker payudara jarang terjadi pada perempuan yang berusia kurang dari 30 tahun. Pada usia $\geq 30$ tahun atau 40 tahun keatas disebut masa pramenopouse, pada masa ini kadar hormon estrogen dan progesteron mengalami pertumbuhan abnormal sehingga produksi hormon estrogen semakin meningkat dan hal inilah yang memicu untuk terjadinya kanker (Rahayu \& Arania, 2018). Hormon estrogen diperlukan untuk perkembangan seksual dan fungsional organ-organ kewanitaan secara normal terutama dengan kemampuan melahirkan anak seperti uterus dan ovarium. Estrogen juga memiliki peran terhadap siklus menstruasi dan pertumbuhan payudara secara normal (Rahayu \& Arania, 2018). Hasil penelitian ini menyatakan 
ada hubungan wanita usia $\geq 30$ tahun dengan kejadian tumor ganas payudara (Cl 95\% 4,02-89,6). Hal ini sejalan dengan penelitian Rahayu \& Arania 2018 di RSUD Dr. H. Abdul Moeloek Bandar Lampung Tahun 2017 dengan nilai OR = 14,00 . Penelitian tersebut menyatakan bahwa wanita usia $\geq 30$ tahun sebanyak 56 orang dan wanita usia tersebut berpeluang 14,00 kali menderita kanker payudara di RSUD Dr. H. Abdul Moeloek Bandar Lampung Tahun 2017 (Rahayu \& Arania, 2018).

Usia merupakan salah satu faktor risiko terjadinya tumor ganas payudara, karena didasari teori bahwa pajanan hormon dalam jangka waktu yang lama serta adanya pajanan dari faktor risiko lainnya dapat menginduksi terjadinya tumor ganas payudara (Setiadharma et al., 2019).

\section{Risiko Riwayat Melahirkan terhadap Kejadian Tumor Ganas Payudara}

Wanita yang tidak pernah melahirkan atau nullipara berisiko terkena tumor ganas payudara lebih tinggi. Kadar hormon estrogen yang tinggi selama masa reproduktif wanita, terutama jika tidak diselingi oleh perubahan hormonal pada kehamilan akan meningkatkan sel-sel yang secara genetik telah mengalami kerusakaan dan menyebabkan kanker. Hal ini disebabkan karena wanita nullipara tidak pernah menyusui. Wanita yang menyusui kadar estrogen dan progesteron akan tetap rendah selama menyusui sehingga mengurangi pengaruh hormon tersebut terhadap poliferasi jaringan termasuk jaringan payudara (Rahayu \& Arania, 2018).

Dalam penelitian ini wanita yang tidak pernah melahirkan memiliki hubungan yang signifikan dengan kejadian tumor ganas payudara (CI 95\% 1,70-2,78). Hal ini serupa dengan penelitian Setiadharma et al., 2019, dalam penelitiannya di RSUP Dr. Kariadi dan RS Ken Saras Semarang Tahun 2018 dengan nilai $\mathrm{OR}=9,333$, CI 95\% $=1,052$ 82,780 ). Penelitian tersebut menyatakan sebayak 7 orang dari kelompok kasus yang tidak pernah melahirkan dengan peluang 9,333 kali dibanding dengan wanita yang pernah melahirkan (Setiadharma et al., 2019)

\section{Risiko Riwayat Menyusui terhadap Kejadian Tumor Ganas Payudara}

Menyusui menjadi faktor yang protektif terhadap kejadian tumor ganas payudara. Kadar hormon estrogen dan progesteron yang tinggi selama masa kehamilan akan menurun setelah melahirkan karena mekanisme menyusui. Menyusui dapat membuat kadar hormon estrogen dan progesteron menurun sehingga mengurangi pengaruh hormon tersebut terhadap poliferasi jaringan di payudara (Fauzia, 2019).

Riwayat menyusui dalam penelitian ini bukan merupakan faktor risiko dikarenakan responden yang kebayakan merupakan responden mulitipara atau wanita yang pernah melahirkan lebih dari 1 kali atau pernah melahirkan 2 kali dalam waktu 20 bulan. Wanita yang multipara memiliki produksi air susu yang bayak dibanding wanita yang riwayat melahirkannya hanya 1 kali, karena peningkatan kadar hormon dalam darah dihubungkan dengan peningkatan poliferasi sel payudara. Peningkatan kadar hormon yang meningkatkan poliferasi sel sebanding dengan kadar hormon yang menurunkan poliferasi sel payudara (Rahayu \& Arania, 2018).

Wanita yang pernah menyusui $<2$ tahun tidak memiliki hubungan terhadap tumor ganas payudara (OR 1,00 $\mathrm{Cl} 95 \%$ 0,39-2,50). Hasil penelitian ini sejalan dengan penelitian Setiadharma et al., 2019, dalam penelitiannya di RSUP DR. Kariadi dan RS Ken Saras Semarang pada tahun 2019 menunjukkan bahwa riwayat menyusui bukan merupakan faktor risiko tumor payudara. Penelitian Setiadharma et al., 2019 tidak memilki hubungan karena kebayakan sampel penelitian menyusui selama kurang dari 12 bulan, sehingga tidak memberikan efek proteksi yang maksimal terhadap kejadian tumor payudara (Setiadharma et al., 2019).

Meskipun dalam penelitian ini didapatkan bahwa menyusui selama $<2$ tahun bukan merupakan faktor risiko kejadian tumor ganas payudara, namun menyusui dapat mempengaruhi tingkat estrogen dalam tubuh, yang mana hormon estrogen pada wanita adalah bahan utama penyebab kanker payudara. 
Sehingga waktu menyusui yang lebih lama mempunyai efek positif dalam menurunkan risiko kanker payudara dimana terjadi penurunan kadar hormon estrogen dan pengeluaran bahan-bahan pemicu kanker selama proses menyusui. Semakin lama waktu menyusui semakin besar efek perlindungan terhadap kanker payudara. Oleh karena itu risiko kanker payudara akan menurun jika perempuan sering menyusui dan dalam jangka waktu yang lama atau $\geq 2$ tahun (Sukmeyenti \& Sari, 2019).

Jadi proses menyusui pada wanita yang sudah melahirkan merupakan hal penting atau suatu kewajiban yang harus dilakukan, sehingga dapat mengurangi risiko terkena tumor ganas payudara. Dalam hal ini, peneliti berikutnya dapat menggali lebih rinci tentang proses pemberian ASI. Sehingga dapat menjawab hipotesis tentang proses menyusui memiliki hubungan terhadap kejadian tumor ganas payudara.

\section{Riwayat Keluarga terhadap Kejadian Tumor Ganas Payudara}

Wanita yang memiliki riwayat keluarga dapat meningkatkan peluang terkena tumor ganas payudara. Semakin muda anggota keluarga tersebut terkena kanker payudara maka akan semakin besar pula penyakit tersebut bersifat menurun. Wanita yang memiliki hubungan kekeluargaan dengan penderita kanker payudara memiliki risiko yang lebih besar, terutama jika hubungannya dekat. Hal ini karena mutasi gen yang mungkin diwarisi oleh keluarga dekatnya (Maulinasari et al., 2018).

Wanita yang mempunyai keluarga yang pernah menderita tumor atau kanker payudara berisiko terhadap kejadian tumor ganas payudara, dengan peluang 6,33 kali dibanding waita yang tidak memiliki riwayat keluarga. Penelitian ini diperkuat dengan penelitian Maulinasari et al., 2018, dalam penelitiannya di RSUD Dr. Pirngadi Medan Tahun 2017 dengan nilai $\mathrm{OR}=9,056$, CI $95 \%=3,586-$ 22,871 . Risiko kanker payudara pada wanita akan meningkat apabila wanita memiliki hubungan darah dengan penderita kanker payudara (Maulinasari et al., 2018).

Risiko Riwayat Menopause terhadap

\section{Kejadian Tumor Ganas Payudara}

Menopause adalah berhentinya seorang wanita menstruasi secara permanen. Semakin tua usia seseorang saat awal menopause maka memiliki risiko lebih besar terkena kanker payudara dibandingkan wanita yang mengalami menopouse lebih muda. Menopouse terjadi pada usia yang bervariasi, terjadi rata-rata usia menopouse 45-50 tahun dengan gambaran klinis normal menstruasi berhenti. Wanita mengalami menstruasi pada usia yang berbeda, yaitu sebelum usia 48 tahun atau sesudah 48 tahun (Neila et al., 2018).

Semakin tua seseorang saat awal menopouse maka memiliki risiko lebih besar terkena kanker payudara dibandingkan wanita yang mengalami menopouse lebih muda. Pada wanita yang mengalami awal menopouse usia yang lebih tua berarti lebih lama terpapar dengan tingginya hormon estrogen dalam darah. Sedangkan peran hormon estrogen pada wanita menopouse adalah tingkat estrogen yang lebih tinggi pada seorang wanita akan menghambat terjadinya menopouse sehingga mengembangkan risiko terjadinya kanker (Neila et al., 2018). Hasil penelitian ini menyatakan wanita yang mengalami usia menopause $\geq 50$ tahun memiliki 2,33 kali berisiko terhadap kejadian tumor ganas payudara (Cl 95\% 1,78-3,05). Hal ini didukung dengan adanya penelitian Neila et al., 2018 dalam penelitiannya di RSUD Dr. Achmad Mochtar dengan nilai $\mathrm{OR}=$ 2,935 .

Risiko Riwayat Pemakaian Alat Kontrasepsi Hormonal terhadap Kejadian Tumor Ganas Payudara

Hubungan payudara adalah kandungan estrogen dan progesteron yang ada dalam kontrasepsi. Penggunaan kontrasepsi hormonal akan meningkatkan pajanan hormon estrogen dan progesteron tubuh, terutama pada payudara (Fauzia, 2019). Pemakaian kontrasepsi hormonal dapat meningkatkan paparan hormon estrogen dalam tubuh. Adanya penigkatan paparan hormon estrogen tersebutlah yang dapat memicu pertumbuhan sel yang berlebihan sehingga dapat menimbulkan 
adanya kanker (Nissa et al., 2017).

Penggunaan kontrasepsi homonal yang terus menerus dalam jangka waktu yang panjang dapat menyebabkan kadar estrogen dan progesteron meningkat dalam tubuh (Neila et al., 2018). Sehingga semakin banyak jumlah estrogen dalam tubuh dapat memicu pertumbuhan sel secara tidak normal pada bagian tertentu misalnya payudara. Karena pertumbuhan jaringan payudara sangat sensitif terhadap estrogen maka wanita yang terpapar estrogen dalam waktu yang panjang akan memiliki risiko yang besar terhadap kanker (Maulinasari et al., 2018).

Hasil analisis besar risiko riwayat pemakaian alat kontrasepsi hormonal terhadap kejadian tumor ganas payudara $\geq 5$ memiliki peluang 6,33 kali berisiko terkena tumor ganas payudara dibanding wanita yang memakai alat kontrasepsi hormonal $<5$ tahun. Hal ini diperkuat dengan penelitian Nissa et al., 2017 dalam penelitiannya di RSUD Al-Ihsan Bandung Tahun 2017 dengan nilai $\mathrm{OR}=$ 2,81 , CI $95 \%=9,10-11,4$. Kurangnya pengetahuan dan penyuluhan yang diberikan oleh petugas kesehatan tentang lama penggunaan kontrespesi hormonal berhubungan dengan kejadian tumor ganas payudara.

Jenis kontrasepsi hormonal yang paling berisiko adalah jenis oral (pil). Kontrasepsi oral yang paling banyak mengandung kombinasi estrogen dan progesteron. Wanita yang menggunakan kontrasepsi oral dalam jangka waktu yang lama dapat mengganggu keseimbangan hormon estrogen dalam tubuh dan dapat mengakibatkan perubahan sel yang normal menjadi tidak normal (Maulinasari et al., 2018).

\section{KESIMPULAN}

Berdasarkan hasil penelitian yang telah dilakukan, maka dapat disimpulkan bahwa usia, riwayat melahirkan, riwayat keluarga, riwayat menopouse, dan riwayat pemakaian alat kontrasepsi hormonal merupakan faktor risiko kejadian tumor ganas payudara di RSUD Andi Makkasau Kota Parepare sedangkan riwayat menyusui bukan merupakan faktor risiko kejadian tumor ganas payudara di RSUD Andi
Makkasau Kota Parepare.

Disarankan kepada petugas kesehatan untuk memberikan penyuluhan kepada wanita mengenai fakto-faktor penyebab kejadian tumor ganas payudara dan untuk peneliti selanjutnya melakukan penelitian dengan variabel yang berbeda yang mampu menggambarkan faktor risiko tumor ganas payudara yang jelas dan melakukan penelitian tentang lama menyusui dengan tumor ganas payudara

\section{DAFTAR PUSTAKA}

Astria, N., Yerizel, E., \& Khambri, D. (2020). Perbedaan Usia Menarche dan Indeks Massa Tubuh (IMT) pada Penderita Kanker Payudara dan Bukan Penderita Kanker Payudara. Jurnal Ilmiah Ilmu Kesehatan, 6(1), 25-30.

Fauzia, R. A. (2019). Hubungan Riwayat Reproduksi dengan Tumor Payudara pada Perempuan Usia Muda di Indonesia (Analisis Riset PTM 2016). Media Kesehatan Masyarakat Indonesia, 15(3), 237244.

https://doi.org/10.30597/mkmi.v15 i3.6278

Kemenkes RI. (2018). Data dan Informasi profil Kesehatan Indonesia 2018. Data Dan Informasi Profil Kesehatan Indonesia.

Maulinasari, W. N., Asfriyati, \& Siregar, F. A. (2018). Pengaruh Pemakaian Kontrasepsi Hormonal dan Riwayat Keluarga Terhadap Kejadian Kanker Payudara di Rsud Dr . Pirngadi Medan Tahun 2017. Jurnal Medika Respati, 13(2), 3947.

Neila, S., Yananda, R., \& Adriani. (2018). Determinan Kejadian Ca Mammae Di Poli Rawat Jalan Bedah Rsud Dr. Achmad Mochtar. Jurnal Endurance, 3(3), 575-587. https://doi.org/10.22216/jen.v3i3.3 700

Nissa, P. A. E., Hidayat, W., \& Purbaningsih, W. (2017). Kontrasepsi Hormonal sebagai Faktor Risiko Kanker Payudara di RSUD Al-Ihsan Bandung. Bandung Meeting on Global Medicine \& 
Health (BaMGMH), 1(1), 112-119.

Rahayu, S. A., \& Arania, R. (2018). Hubungan Usia Dini dan Paritas dengan Kejadian Kanker Payudara di RSUD Dr. H. Abdul Moeloek Bandar Lampung Tahun 2017. Jurnal Ilmu Kedokteran Dan Kesehatan, 5(1), 44-50.

Rukinah. (2019). Gambaran Pengetahuan Wanita Usia Subur Tentang Pencegahan Kanker Payudara Di Puskesmas Maccini Sawah Makassar 2019. Jurnal Farmasi Sandi Karsa, 5(1), 84-89.

Setiadharma, A., Kuntjoro, R. L. P. W.,
\& Utomo, A. W. (2019). Hubungan Penggunaan Kontrasepsi Hormonal Terhadap Kejadian Tumor Payudara : Studi Pada Wanita Yang Melakukan Pemeriksaan Ultrasonografi Payudara Di Rsup Dr. Kariadi Dan Rs Ken Saras, Semarang. Jurnal Kedokteran Diponegoro, 8(2), 892-909.

Sukmeyenti, \& Sari, N. (2019). Ananlisi Determinan Kanker Payudara Pada Wanita Di RSUP DR. M. Djamil Padang Tahun 2018. Jurnal Kesehatan, 1(1), 77-86. 